\title{
THE EFFECTS OF PSYCHOLOGICAL CONTRACT BREACH TO THE ORGANIZATIONAL AFFECTIVE COMMITMENT: THE CASE SELECTED PUBLIC UNIVERSITIES IN TANZANIA
}

\author{
Chacha Matoka $^{1}$ and William Amos Pallangyo ${ }^{2}$ \\ ${ }^{1}$ Lecturer- The Open University of Tanzania, P.O. Box 23409 Dar es salaam \\ ${ }^{2}$ Senior Lecturer-The law School of Tanzania, P.O. Box 9422 Dar es Salaam \\ DOI: 10.46609/IJSSER.2020.v05i02.017 URL: https://doi.org/10.46609/IJSSER.2020.v05i02.017
}

\begin{abstract}
This article analyses the effects of Psychological Contract Breach (PCB) on Organizational Affective Commitment (OAC) of public universities' academic staff in Tanzania. A crosssectional survey was carried out on a sample of 187 academic staff. Descriptive statistics, correlation, linear and multiple linear regression analysis techniques were applied. The study found that perceived PCB significantly negatively affected OAC. Respondents aged 51and above have higher affective commitment than those in the younger group (21- 30 years). Married couples showed a higher Affective Commitment than the rest of the other groups. Senior lecturers and above academic ranks had lower AC compared to below groups. Academic staff with administrative roles had lower AC than those without any administrative positions at universities. The study recommends to universities management to ensure fulfillment of its promises to academic staff. Young academic staff can be motivated through further training and engagement in research and consultancy. Contrarily, the older groups could be guaranteed their tenure and good pay.
\end{abstract}

Keywords: Psychological contract, organizational commitment and Public Universities

\section{INTRODUCTION}

The contemporary organizations are characterized by high competition for survival and the commitment of employees is a critical resource. The public universities like any other organizations need to have a highly committed workforce especially the academic staff who do the core function of education provision to students. The organizational commitment concept is recognized as one of the critical factors of organizational success (Alsiewi \& Agil, 2014). 


\section{International Journal of Social Science and Economic Research}

ISSN: $2455-8834$

Volume: 05, Issue: 02 "February 2020"

Moreover, organizational commitment is increasingly attracting studies in the process of increasing employees' morale, motivation, performance, organizational citizenship, and employees' retention (Chordiya, et al. 2017; Gunlu, et al. 2010). Organizational commitment is considered as a cornerstone of employee performance (Tolentino, 2015), core of human resource management practice (Gbadamosi et al., 2007) and it increases the success of organizational objectives (Khalili \& Asmawi, 2012).

The organizational commitment is linked with positive organizational outcomes such as efficiency, growth and development (Khaleh \& Naji, 2016), profitability and competitiveness (Ramay \& Ramay, 2012), service quality (Shangholi, et.al, 2011), and job performance (Chungtai \& Zafar, 2006). Organizational commitment is also known in the reduction of the negative outcomes such as absenteeism (Mathew \& Zajac, 1990) and turnover intentions (Jonathan, et. al, 2013).

Contrarily, psychological contract breach is a perception by employees which leads them to less commitment to the organization, its vision, mission and values. The perception of the psychological breach can accrue when individuals perceive weak congruence between themselves and their organization (Southcombe et al., 2015). The psychological contract can also be defined as a series of mutual expectations of which the parties may not themselves be dimly aware which nonetheless govern their relationship to each other (Levison et al., 1962). The psychological contract is an unwritten, understanding, and it is informal obligations between employer and employees regarding their mutual obligations of how each will perform their tasks with a typical trust.

The ability to attract, retain and develop competent employees is vital for all organizations. However, such ability is more important to universities because of the Universities' dependence on the knowledge and abilities of their academic workforce (Alvesson, 2004). The difficulty and ambiguity of academic work (Benson \& Brown, 2007), the worldwide demand for and scarcities of quality academics, the ageing academic workforce, and high costs associated with the replacement of competent academic workers (Southcombe et al., 2015), further challenge universities to recruit, develop and retain committed academic staff.

Employees are the most incalculable assets of an organization (Voon et al., 2011), but academic staff are the backbone of universities; and high turnover rates among them have a damaging effect on the growth of universities (Li et al., 2017), students' education and successes (Mclnerney et al., 2015) and the image of academic sector overall (Alzubi, 2018).

Since highly committed academic staff play an essential role in the success of universities (Ahmad et al., 2017), university managers seeking a competitive advantage are required to 


\section{International Journal of Social Science and Economic Research}

ISSN: $2455-8834$

Volume: 05, Issue: 02 "February 2020"

understand the commitment of academic staff to their universities, as well as the underlying antecedents. Universities in East Africa have been characterized by reported grievances from their academic staff members over the year Koskei et al. (2018). Many of such grievances are centered on issues related to rewards, working environment as well as career development conditions and opportunities against not only the statutory provisions but also what is expected of a university (normally unwritten). The latter's grievance may lead to academic staff's feeling of a psychological breach between them and their universities (the employer).

Academic staffs show low morale of teaching, researching and publications. Instead, they endeavor to their private generating income projects and consequently jeopardizing the quality of academic service to their universities and a country as a whole. Evidenced by the presumed low quality of products as university graduates fail to fulfill job demands (Hum, 2016). The PhD holders are keen on consultancies and not committed to academic teaching. They claim to be busy with their research and consultancies, as a results untrained staff and junior lecturers handle academic matters at universities. For example, it is reasonable to find Tutorial Assistants with Bachelor degree teaching undergraduates contrary to the Tanzania commission for Universities (TCU) regulations which require one to have at least a Master's degree (Hum, 2016).

Some evidence reveals that academic staff engages in strikes, threatening for strikes and frequent absenteeism. For example, University of Dar es salaam Academic staff Association (UDASA, which is University of Dar es Salaam academic staff frequently have been threatening strikes due to their demands not met or just partially met like pay increase, areas and house allowances. Other academic staff sometimes delay student's examination results, sometimes engage in parttime teaching at other private universities or own business entrepreneurship. These are symptoms of affected motivation and commitment. In other words, if this problem of lack of employee commitment continues to persist among academic staff at public universities, in the end, there will be a total or complete fall in the academic standards on Tanzania universities (Ishengoma, 2017).

Many of the issues aforesaid are predominant in public universities. Therefore, the present study was designed to study the affective organizational commitment of the academic staff of public universities and determine whether such commitment is affected by perceived psychological contract breach, based on the social exchange theory.

\section{ORGANIZATIONAL COMMITMENT OF UNIVERSITY ACADEMIC STAFF IN TANZANIA}

Tanzania is a developing country characterized by low development. In order to leap from that situation, the education sector is one of the important factors and mover for the development of 


\section{International Journal of Social Science and Economic Research}

ISSN: $2455-8834$

Volume: 05, Issue: 02 "February 2020"

people, economy, science and all aspects of life. Currently, there is a focus and vision of the nation embarking from being a poor and undeveloped country to be an industrial and medium economy by 2025. Achieving this vision requires a commitment from all sectors but most important from high learning institutions and universities in particular. Academic staffs at universities are the core elite to the function of university success and education in general of the country. They have a huge role, for example, they are the breeders of scientists, managers, decision-makers of all fields, they develop and review study curriculum and also, they solve community problems through consultancies and last, they create and transfer knowledge through research.

Our education system is still perceived to be low, therefore demands huge investments in human capital. Few studies have been conducted explaining the current situation of lack of commitment among academic staff at universities; poor compensation, little attention to training opportunities, poor social and family facilities and huge workload lecturer student ratio. It is due to the above reasons that academic staffs are not imparting adequate knowledge to the students. Therefore, university products not fulfilling the job market demand (Sial et al 2011). Academic staffs are perceived to be committed when their needs, for example, are aligned with university values, mission and objectives. This is known as affective commitment. Another academic staff becomes committed because leaving their current job may affect their prestige, social networks and benefits. This is known as continuance commitment. Yet others become committed to universities because they perceive as their obligation to do so. This is known as normative commitment.

Each of the three dimensions of commitment is experienced at different degrees by all academic staff (Islam et al 2012). However, this study focused on affective commitment dimension.

As pointed above academic staffs that are committed to their universities are expected not only to emphasize upon their duties being the best performers to achieve their objectives but also staying to their universities. Therefore, attracting developing and retaining committed academic staff has become an important factor to achieve university goals (Saifuddin et al 2012). University management has to control the perceived deterrent of psychological contract breach so as to bring a positive perception of academic staff and therefore becomes committed in order to be able to succeed in the provision of high quality and relevant education and knowledge to the society.

\section{Psychological Contract Breach}

The psychological contract has a root from the employment relationship. Employers and employees are always engaged in a relationship whereby each part has an obligation toward 


\section{International Journal of Social Science and Economic Research}

ISSN: $2455-8834$

Volume: 05, Issue: 02 "February 2020"

another part. The relationship between employer and employee has been changing over time due to the influence of globalization, technological advancement, socio-political and economic events (Morris \& Robinson, 1997).

Conway and Shapiro (2009) define psychological contract breach as an employee's perception that his or her organization has failed to fulfil one or more obligation associated with the perceived mutual promise. They argue that any inconsistency with the employee's belief in a reciprocal obligation has the potential to create a perception of psychological contract breach.

In early studies, researchers used the psychological contract breach and violation interchangeably (Morrison \& Rousseau, 1997). They distributed the two terms of cognitive and emotional. Contract violation includes emotional distress, feelings of betrayal, anger and wrongful harm that result from the individual perception that although they have kept that promise of another party, the other party broke the promise to the individual.

The breach may occur but not a violation. Conway and Brinner (2002) provide that, psychological contract breach leads to reduced organizational commitment among employees.

Psychological contract breach may occur when recruiters may over-promise a job applicant for challenges, growth and development. It is known as reneging or when managers or coworkers may have different perceptions that, weather obligation do exist or not. It is called incongruence contract (Robison \& Rousseau, 1994)

Therefore, failure to honour a contract creates a sense of wrongdoing of deception and betrayal with persuasive implications for the employment relationship (Rousseau, 1989). Hence the psychological contract breach tends to decrease trust. This argument is supported by Shields (2007), who hints that psychological contract breach can occur because of contract drift. A divergence of what is involved in the exchange relationship and what each party believes should be involved. It is therefore expected that both concepts - perceived psychological contract breach and organizational commitment - form part of the reciprocal exchange and would be related. That is, when employees perceive that the psychological contract between them and the employer has been breached, they reciprocate with low commitment to the organization, its vision mission and values, leading to a negative relationship between the two concepts.

However, little empirical research has been done on the link between perceived psychological contract breach and organizational commitment (Antonaki, Trivellas, 2014; Hazrat, 2017), and none in Tanzania. Although there have been a few studies on organizational commitment in Tanzania, none of them is linked to perceived psychological contract breach. See, for example, Jonathan, Thibeli, and Darroux (2013) and Jonathan, Darroux and Maselle (2013) who linked it to demographic factors and job satisfaction, Ngatuni (2019) who linked it to job involvement and 
International Journal of Social Science and Economic Research

ISSN: $2455-8834$

Volume: 05, Issue: 02 "February 2020"

perceived supervisory support, and Nguni (2006) who linked it to leadership styles. Sector wise, all these studies, except Ngatuni (2019), focused on the education sector, investigating the organizational commitment of primary school teachers (Nguni, 2006) and secondary school teachers (Jonathan, Thibeli \& Darroux, 2013). However, higher education - specifically academic staff of public universities have not listed anywhere been studied.

\section{Components of psychological contract breach}

The psychological contract breach is characterized by several components that affect the exchange relationship between employer and employees.

\section{Delay}

Delay is a breach. This is defined as the time lag between the expected fulfilment of the promise and the actual point of delivery. Casser and Brinner (2011) show that, the delay in pay provides the basis for continuing imbalance exchange and necessitates trust to be low. The very long delay is interpreted as perceived as a breach since trust also determines when the delivery was expected. Therefore, delay is seen and interpreted feature amongst the list of breach or discrepancies.

\section{Magnitude}

Magnitude is the second component perceived as a breach. It occurs when what is delivered is less than what is assured before. Shoe and Tetrick (1994) and Turnley \& Feldman (1999) note that the discrepancy, in magnitude, tends to affect the employee's reaction to commitment negatively.

\section{The form}

This breach occurs when what is delivered is of different type or form from what has been promised before (Conaway \&Brinner, 2009). For example, an employee receiving in-house training instead of been sent abroad for training as initially promised.

\section{Inequity}

Refers to a situation of a breach where the employees believe or perceive that what they are getting is less than or different from what others in similar positions or work are getting. Adam (1965) provided equity theory in exchange by asserting that, people tend to compare their input to output ratio with a comparison. Therefore, testing fairness is advisable. When employees perceive that, there is no fairness. They are influenced negatively towards organizational commitment. 
International Journal of Social Science and Economic Research

ISSN: $2455-8834$

Volume: 05, Issue: 02 "February 2020"

\section{Exchange imbalance}

This is referred to as a perceived breach that occurs when the employees perceive that they are giving far too much to the organization than they are receiving back in return. Morrison \& Robinson (1997) and others Coyle-Shapiro (2002) suggest exchange breach itself does not lead to violation unless the employees perceive that he or she has made a contribution that has not been reciprocated as promised.

\section{REVIEWED THEORIES}

\section{Organizational commitment theories}

In theoretical aspects, organizational commitment is a mindset or physical state of feelings and beliefs concerning an employee's relationship with an organization (Meyer \&Allen, 1991). Viewing the two approaches of commitments, attitudinal and behavioural (Mauday et al., 1982); attitudinal commitment deals with the process in which people think about a relationship with the organization. It is the mindset in which people think to what extent their values and goals are congruent to those of the organization. While behavioural commitment relates the process by which people become locked in a particular organization and how they deal with the problem in their organization.

In attitudinal commitment, the research has been directed mainly at the identification of the conditions that contribute to the development of commitment (Steers, 1977). While in behavioural commitment the research has focused on conditions under which behavior exhibited tend to repeat. Meyer and Allen (1991) provide a complementary relationship between behavioural and attitudinal commitment contrary to Mauday et al. (1982) who focus only on values and goals congruence. Meyer \& Allen (1991) argue that organizational commitment should reflect a decisive, need and obligation to maintain membership in the organization. They also provide organizational commitment into three dimensions, namely affective, continuance and normative commitment as defined above.

The three approaches, all have similar characteristics. Employee relationship with the organization is primary and that, employees have jurisdictions for deciding to continue or discontinue membership with the organization. This is due to differences in how they perceive their psychological contract with the organization (Meyer \& Allen, 1991). In affective commitment employees' emotional attachment is evidenced, continuance commitment which is the awareness of the cost of leaving the organization. Employees continue in the organization because they need to do so, as supported by the side-bet theory of (Becker, 1960). On the other hand, normative commitment is the feelings of obligation to continue working with the organization. 


\section{International Journal of Social Science and Economic Research}

ISSN: $2455-8834$

Volume: 05, Issue: 02 "February 2020"

Therefore, it seems more reasonable to expect that employees can experience all three forms of commitment to a varying degree (Meyer \& Allen, 1991). For example, an employee may feel a strong desire and a strong need to remain but little obligation to do so. Or little desire, moderate need and a substantial obligation. Most important is to what extent the psychological contract influence commitment. It is likely that the psychological state reflecting the three components of commitment and their implications for the whole relevant behaviour of the employees. However, the three-component model of organizational commitment critics is that the three bases are possibly three distinct constructs (Rodrigues \& Bastos, 2010).

The relationship of employee commitment to its background. This study linked psychological contract beach and employee commitment, by looking at the social exchange theory, which suggests that Human resource management practices do contribute to favorable exchange relationships between academic employees and their employers. The positive relationship reached when employees perceive their demands fulfilled by their employer. individual employees do reciprocate to the favorable positive environment (Marescaux \& Sels, 2013). Geetha and Mamphilly. (2012) show that the core principles with social exchange theory are that employees see the sustaining human resource practices as the organization's commitment towards them. Therefore, employees do reciprocate by positive behaviuor like employee's commitment by working hard, spent long hours at university engaging in academic matters. Based on this theory the researcher has a reason to suggest that human resource practices may lead to either positive or negative employees' commitment.

The psychological contract has a root from the social exchange theory, which states that individual will search for fair and balanced exchange relationship (Homans, 1958). The employees believe that promise made and a considerable offered in exchange for it, bringing the parties to some set of reciprocal obligations as psychological contact (Becker, 1960; Rousseau, 1989; Bedillet \& Dwivendula, 2010). Hence, they came up with the side-bet theory. That commitment came into being when a person by making a side bets likes extraneous interest with a consistent line of activity. Therefore, they find that there is a direct correlation between age, marital status, number of children and pay, showing that older people with higher income make side bets in an additional commitment around marriages and having children that effectively increase their commitment in the job.

Therefore, the exchange theory argues that psychological contract breach leads to possible adverse effects on some vital employee job linked attitudes and behaviours. The reason is that the psychological contract breach tends to lead to the emerging of an employment relationship based on harmful reciprocal norms. Cropanzano \& Mitchel (2005), Zhao et al. (2007), Shapiro et al. (2008), and Chen \&Tetrick (2009) provide a quantitative theory trying to explain the 


\section{International Journal of Social Science and Economic Research}

ISSN: $2455-8834$

Volume: 05, Issue: 02 "February 2020"

psychological contract from the social exchange point of view. Basing on their quantitative study, they state that, there is an impression that the relationship between psychological contract breach employees is reciprocating in a simple and linear one. They contend that a psychological contract is a schema of employee and employers' relationship. The schema guides and directs individual perception of inquiring information, the retrieval is the inferences based on that information so that it is relevant and profitable consistent with the existing schema. Social exchange theory is related to psychological contract as it reflects the expectations of the employee and the organization has regarding the particular resource to each other (Manzoor 2016). In connection with this study, the social exchange theory set a sense that psychological contract is the mutual obligation of employees and their employer. Manzoor (2016) continue to show that, the social exchange theory explains how employees feel about a relationship with their organization return of obligation.

Two main critique of this theory is that, it can be leveled against the social exchange theory. Firstly, is how the treatment of people's behaviors or social exchange life as an exchange. It disregards of the sociological ideas on Meta theoretical or the rigid grounds that they are holistic or cultural crust is mismatched with its individualist, utilitarian and behaviorist core. The second aspect is that it has reduced the social interaction or exchange to monetary transactions or psychological process. The society has influence of behavior as cultural effects therefore employees not really free and independent to choose on their own. They are attached to the society as contrary to psychological contract and social exchange theory focus on an individual person ignoring other influences of behavior.

\section{METHODOLOGY}

The study was descriptive quantitative, where a cross-sectional survey was used to provide information of the university academic staff. The approach permitted easy comparison and understand and explanation of the study phenomenon (Saunders et al., 2012). The chosen public universities included the University of Dar es Salaam (UDSM), Open University of Tanzania (OUT) and Muhimbili University of Health and Allied Sciences (MUHAS), Sokoine University of Agriculture (SUA) and Mzumbe University (MU). The population of the study of the academic staff in the five (5) public universities is summarized in table 1. 
International Journal of Social Science and Economic Research

ISSN: $2455-8834$

Volume: 05, Issue: 02 "February 2020"

Table 1: Academic staff in the selected public universities

\begin{tabular}{lccccccccccc}
\hline & \multicolumn{2}{l}{ Professors } & \multicolumn{3}{l}{$\begin{array}{l}\text { Senior } \\
\text { lecturers }\end{array}$} & Lecturers & & Asst. lecturers & Tutorial \\
assistants & Total \\
University & male & female & male & female & male & Female & male & female & male & female \\
UDSM & 23 & 6 & 78 & 57 & 108 & 71 & 92 & 64 & 21 & 17 & $\mathbf{5 3 7}$ \\
OUT & 13 & 4 & 13 & 5 & 32 & 24 & 93 & 84 & 21 & 13 & $\mathbf{3 0 2}$ \\
SUA & 32 & 23 & 48 & 26 & 63 & 44 & 72 & 53 & 28 & 19 & $\mathbf{4 0 8}$ \\
MU & 11 & 2 & 20 & 6 & 83 & 49 & 68 & 41 & 15 & 9 & $\mathbf{3 0 4}$ \\
MUHAS & 17 & 4 & 42 & 31 & 75 & 41 & 42 & 23 & 20 & 9 & $\mathbf{3 0 4}$ \\
TOTAL & $\mathbf{9 6}$ & $\mathbf{3 9}$ & $\mathbf{2 0 1}$ & $\mathbf{1 2 5}$ & $\mathbf{3 6 1}$ & $\mathbf{2 2 9}$ & $\mathbf{3 6 7}$ & $\mathbf{2 6 5}$ & $\mathbf{1 0 5}$ & $\mathbf{6 7}$ & $\mathbf{1 8 5 5}$ \\
\hline
\end{tabular}

Source: TCU2019

The study applied Green (1991) formula with a more significant number than 50 as validated by Comrey and Lee (1992) rule of thumb formula, $\mathrm{n}=50+8 m$ where $m$ is the number of independent variables. It provides a guide for sample size as 50, poor, 100 still weak and 200 reasonably well. Therefore 200 respondents were targeted as a sample size in order to cater for non-responses.

$\mathrm{N}=50+(8 \times 12)=146$ as a minimum sample. In order to make sure that the sample is correctly obtained the numbers were to 200 as suggested by Pallant (2010)

Table 2: Sample from the selected public universities

\begin{tabular}{cccc}
\hline University & Population & Computation & Sample \\
\hline UDSM & 537 & $\frac{537 \times 200}{\underline{1855}}$ & 58 \\
OUT & 302 & $\underline{302 \times 200}$ & 33 \\
SUA & 408 & $\frac{408 \times 200}{1855}$ & 44 \\
MU & 301 & $\frac{304 \times 200}{1855}$ & 32
\end{tabular}


International Journal of Social Science and Economic Research

ISSN: $2455-8834$

Volume: 05, Issue: 02 "February 2020"

MUHAS

TOTAL
304

1855
304 X 200

1855
33

200

\section{FINDINGS}

Seven demographic variables were involved, namely age, gender, marital status, education level, academic rank, administrative role and experience (Table 3). More than $62 \%$ of the participating academic staff were aged 41 and above. Male academic staffs were 2.3 times the number of female counterparts. The majority $(84 \%)$ were married. PhD holders were about half the sample; the other half was Master degree holders (41\%) and Bachelor degree holders (9.7\%). About $41 \%$ were below the lecturer rank. Only $30 \%$ of the academic staff had administrative duties over and above their academic responsibilities. The academic staff had worked for an average of 12.5 years ranging from a minimum of 1 year to a maximum of 43 years.

Table 3: Sample description

\begin{tabular}{|c|c|c|c|c|c|}
\hline $\mathbf{S} / \mathbf{N}$ & & Frequency & $\%$ & Mean & $\begin{array}{l}\text { Std. } \\
\text { Dev. }\end{array}$ \\
\hline & Age & & & & \\
\hline \multirow[t]{4}{*}{1} & $20-30$ & 18 & 9.6 & & \\
\hline & $31-40$ & 52 & 27.8 & & \\
\hline & $41-50$ & 68 & 36.4 & & \\
\hline & 51 - Above & 49 & 26.2 & & \\
\hline \multirow[t]{3}{*}{2} & Gender & & & & \\
\hline & Male & 129 & 69.4 & & \\
\hline & Female & 57 & 30.6 & & \\
\hline \multirow[t]{4}{*}{3} & Marital status & & & & \\
\hline & Married & 155 & 84.2 & & \\
\hline & Single & 23 & 12.5 & & \\
\hline & Others & 6 & 3.2 & & \\
\hline \multirow[t]{4}{*}{4} & Education & & & & \\
\hline & Bachelor & 18 & 9.7 & & \\
\hline & Masters & 76 & 41.1 & & \\
\hline & Doctorate & 91 & 49.1 & & \\
\hline \multirow[t]{4}{*}{5} & Rank & & & & \\
\hline & Below lecturer & 76 & 41.1 & & \\
\hline & Lecturer & 55 & 29.7 & & \\
\hline & Senior lecturer and above & 54 & 29.2 & & \\
\hline
\end{tabular}


International Journal of Social Science and Economic Research

ISSN: $2455-8834$

Volume: 05, Issue: 02 "February 2020"

6 Administrative

Yes

51

30

No

119

70

7 Experience

$12.48 \quad 8.565$

Source: Field data (2018)

\section{Descriptive statistics Affective Commitment}

Descriptive statistics (mean, standard deviation, minimum, and maximum scores) were computed for the affective commitment scale (Table 4.6). The results show that participating academic staff best showed affective commitment by discussing their respective university with people outside it $(\mathrm{M}=5.38$, S.D. $=1.51)$ followed by the feeling of a strong sense of belongingness to the respective university $(\mathrm{M}=5.30, \mathrm{SD}=1.7)$. The least way through which they showed affection was by the degree to which they could become as attached to another university as they are to the present university $(\mathrm{M}=3.6$, S.D. $=1.85)$

Table 4: Affective Commitment Variables

\begin{tabular}{|c|c|c|c|c|c|}
\hline S/n & Statement & Min. & Max. & Mean & Std. Dev. \\
\hline 1 & $\begin{array}{l}\text { AC } 1 \text { I would be pleased to spend the rest of my } \\
\text { career with this university }\end{array}$ & 1 & 7 & 4.40 & 1.871 \\
\hline 2 & $\begin{array}{l}\text { AC2 I enjoy discussing my university with people } \\
\text { outside it }\end{array}$ & 1 & 7 & 5.38 & 1.506 \\
\hline 3 & $\begin{array}{l}\text { AC3 I feel as if this university's problems are my } \\
\text { own }\end{array}$ & 1 & 7 & 3.83 & 1.948 \\
\hline 4 & $\begin{array}{l}\text { AC4 I think that I could easily become as attached } \\
\text { to another university as I am to this one }\end{array}$ & 1 & 7 & 3.60 & 1.849 \\
\hline 5 & $\begin{array}{l}\text { AC5 I do not feel like 'part of the family' at my } \\
\text { university }\end{array}$ & 1 & 7 & 5.19 & 1.767 \\
\hline 6 & $\begin{array}{l}\text { AC6 I do not feel 'emotionally attached' to this } \\
\text { university }\end{array}$ & 1 & 7 & 4.53 & 1.965 \\
\hline 7 & $\begin{array}{l}\text { AC7 This university has a great deal of personal } \\
\text { meaning for me }\end{array}$ & 1 & 7 & 4.32 & 1.913 \\
\hline 8 & $\begin{array}{l}\text { AC8 I do not feel a strong sense of belonging to my } \\
\text { university }\end{array}$ & 1 & 7 & 5.30 & 1.712 \\
\hline
\end{tabular}

Source: Field data (2018)

Regression Results of OC, AC, CC and NC on PCB 


\section{International Journal of Social Science and Economic Research}

ISSN: $2455-8834$

Volume: 05, Issue: 02 "February 2020"

Affective regression model was run: Results (Table) show that, the variance in AC explained by $\mathrm{PCB}$ was $35 \%, \mathrm{~F}(1,185)=100.90, \mathrm{p}<.001)$. PCB was negatively, and statistically significantly, related to $\mathrm{AC}(\mathrm{b}=-0.744, \mathrm{p}<.001)$.

\section{Whether psychological contract breach, affect Affective University commitment}

Meyer and Allen (2007) provide a general theory of psychological contact and why people stay or commit to an organization. People stay with the organization because they want to. This is affective commitment. They feel an emotional attachment. Employees are expected to show high loyalty, a dedication which is the active elements of commitment. Employees will exhibit a sense of belonging and therefore increase their involvement in their organizational goals. However, if they perceive that there is a psychological contract breach they act adversely to commitment.

This study found that (Table 4.7) psychological contract breach has a negative effect on affective commitment. The relationship is statistically significant and robust. Other previous studies supported by Boylu et al. (2007) found that affective commitment was observed high among other organizational commitment components. That academic staff stay at universities because of their affection to be called lecturers or professors. Alternatively, even just being an academic staff with any rank. This is supported by Meyer and Allen (2007) who found that affective commitment, especially in the modern western world, is predominant among employees. Bergman (2006) found that in modern relationship especially western countries and now supported by this study, affective commitment is affected by psychological contract breach. However, in eastern countries like China and Japan affective sometimes does not make sense at all as employees are working based on collective normativism like family. Cultural cohesion is dominant sometimes challenging to choose as an individual.

An employee's affective commitment is depending on the employee's positive feelings towards the organization and is often the result of organizational policies and activities that promote a positive connection with the workgroup (Meyer \&Allen, 1997).

The more extended member remains in an organization. The more he/she gets attached to it affection ally, and this continuity and long tenure in the organization dampens the intensity of employee's adverse reaction to incidences of the breach. A possible motive for this could be that long-tenured employees are more likely to accommodate and construe contract breach as a natural lapse which will be rectified over time

Interestingly the findings of this study are in contrast to the research of Wu et al. (2006) that reports a weak positive relationship between PCB and affective commitment. These counterintuitive findings are explained concerning potential cultural predispositions toward a balanced 
reciprocity norm in Chinese cultures. Wu et al. (2006) argue that a more immediate economic exchange model may be a key signal in the Chinese culture of mutual trust and loyalty between employer and employee. Given these contrasting findings, much more comparative national and cultural research is needed to explore more specifically the role of contextual factors, such as cultural values and institutional difference, in influencing the nature and role of the relationship between PCB on how it affects commitment.

The study has contributed by presenting an empirical confirmation of reciprocity in the relationship between PCB and employees' affective organizational commitment on academic staff at Tanzania public universities. This is crucial for higher learning institutions to understand how well to retain the high-flying achievers in the academic arena. They are recruited on a real stinger highly competitive with top-class GPAs and still, universities put stinger and severe progression on the academic ladder from tutorial assistant to full professor. For example, apart from demanding publications, still, 4-year duration is a demotivating factor of reducing affection to university.

\section{Descriptive Statistics for Perceived Psychological Contract Breach}

Descriptive statistics (mean, standard deviation, minimum, and maximum scores) were computed for the perceived psychological contract breach scale (Table 4.9). The three items $1-$ 3 (negatively worded) were reverse - coded. The results show that the academic staff's feeling of perceived psychological contract breach was above average as the mean scores ranged from 2.97 to 3.34 (S.D. from 1.12 to 1.8 ).

Table 5: Perceived Psychological Contract Breach Variables

\begin{tabular}{|c|c|c|c|c|c|}
\hline & Statement & Min. & Max. & Mean & Std.Dev. \\
\hline 1 & $\begin{array}{l}\text { PC1 Almost all the promises made by the university } \\
\text { during recruitment have been kept so far }(\mathrm{R})\end{array}$ & 1 & 5 & 3.20 & 1.135 \\
\hline 2 & $\begin{array}{l}\text { PC2 I feel that my university has come through in } \\
\text { fulfilling the promises made to me when I was hired }(\mathrm{R})\end{array}$ & 1 & 5 & 3.06 & 1.181 \\
\hline 3 & $\begin{array}{l}\text { PC3 So far, my university has done an excellent job of } \\
\text { fulfilling its promises to me }(\mathrm{R})\end{array}$ & 1 & 5 & 3.34 & 1.121 \\
\hline 4 & $\begin{array}{l}\text { PC4 I have not received everything promised to me in } \\
\text { exchange for my contribution }\end{array}$ & 1 & 5 & 3.13 & 1.161 \\
\hline 5 & PC5 My university has broken many of its promises to & 1 & 5 & 2.97 & 1.268 \\
\hline
\end{tabular}


International Journal of Social Science and Economic Research

ISSN: 2455-8834

Volume: 05, Issue: 02 "February 2020"

me even though I've upheld my side of the deal

$\mathrm{N}=187$

Variables Descriptive Statistics, Reliability and Correlation Analysis

Descriptive statistics were computed for AC using the cut-off points suggested in Albdour \& Altaraweh (2014), adjusted to 7-point rating levels. Results (Table 4.10) indicated that affective commitment $(\mathrm{M}=4.57, \mathrm{SD}=1.08)$, continuance commitment $(\mathrm{M}=4.03, \mathrm{SD}=.96)$, and normative commitment $(\mathrm{M}=3.48, \mathrm{SD}=.84)$ to their universities were also moderate. The affective commitment had the high mean scores. The correlations between individual dimension and overall affective commitment were between .74 indicating strong and significant relationship (Cohen, 1988).

Using the original cut offs of Albdour and Altarawneh (2014) academic staff had a moderate feeling of psychological contract breach $(\mathrm{M}=4.03$, S.D = .61). Psychological contract breach was significantly negatively correlated with the organizational commitment $\left(\mathrm{r}=-.52^{* *}, \mathrm{p}<\right.$ $.001)$. Affective commitment $(r=-.60, \mathrm{p}<.001)$. Continuance commitment $(\mathrm{r}=-.14, \mathrm{p}=.05)$ and normative commitment $(\mathrm{r}=.19, \mathrm{p}=.01)$

Scale test for reliability analysis was carried out to determine the internal consistency of the measurement's scales. Cronbach's alphas (Table 4.10) in the diagonal show good internal consistency for the affective commitment and psychological contract breach scales $(>7)$, (George and Mallery, 2014).

Table 6: Sample Correlation Matrix and Reliability Statistics

\begin{tabular}{lccc}
\hline Variable & Mean & $\begin{array}{l}\text { Std. } \\
\text { Dev. }\end{array}$ & AC \\
\hline AC & 4.57 & 1.08 & .74 \\
PCB & 3.14 & .86 & $-.60^{* *}$ \\
\hline
\end{tabular}

\section{Regression Results of OC, AC, CC and NC on PCB}

Four regression models were run: $\mathrm{AC}$ on PCB. Results (6) shows that the variance in $\mathrm{AC}$ explained by PCB was $35 \%, F(1,185)=100.90$, p <.001). PCB was negatively, and statistically significantly, related to $\mathrm{AC}(\mathrm{b}=-0.744$, 
International Journal of Social Science and Economic Research

ISSN: 2455-8834

Volume: 05, Issue: 02 "February 2020"

Table 7: Regression Results of AC on PCB

\begin{tabular}{lc}
\hline \multicolumn{1}{c}{ Variables } & $\mathbf{A C}$ \\
\hline Constant & $6.91 * * *$ \\
PCB & $-.744^{* * *}$ \\
Fstat & $100.90^{* * *}$ \\
$\mathrm{R}^{2}$ & .35 \\
\hline tailed), **p $<0.01$ (two - tailed) $* * * \mathrm{p}<0.001($ two - tailed $)$
\end{tabular}

*p $<0.05$ (two - tailed), $* * \mathrm{p}<0.01$ (two - tailed) $* * * \mathrm{p}<0.001$ (two - tailed)

$\mathbf{O C}=$ Organizational Commitment, $\mathbf{A C}=$ Affective Commitment, $\mathbf{C C}=$ continuance commitment $\mathbf{N C}=$ Normative Commitment PCB = Psychological Contract breach Source: Field data (2018)

\subsubsection{Outliers, Normality, Linearity and Homoscedasticity Regression Assumptions Testing Results for AC}

Histogram (figure.1) shows a bell-shaped curve of the distribution of residuals (mean is close to 0 and SD close to 1, evidencing of a normal distribution of residuals). Also, Figure .2 shows that, residuals plot along the diagonal line. Therefore, there is no much deviation from normality. The histogram (Figure 1) shows some of the residual's values lying outside the \pm 3 cut off, evidence of outliers. Tabachnick and Fidell (2007) suggested any value outside the cut off of $|3|$ to be an outlier. Although there is the presence of outliers, little can be done at this point as double deletion of cases may lead to more distortion of the data. During data cleaning cases with values beyond this cut off were deleted using Mahalanobis distance results. Thus, only close monitoring and follow-up is done subsequently.

(Figure 3) shows that case residual dots are not spread rectangularly around zero (0) to infer homoscedacististy (equality of variance). Therefore, there is a suspicion of heteroscedasticity (unequal variance in the data). Subsequently, confirmation using statistical tests was done. Using Ahmad Daryanto plugin on SPSS the Breusch Pagan (BP) and Koenker test were run to confirm this, and the results Table 4. Shows there is no heteroscedasticity (BP, Chi-square $=3.79, \mathrm{p}=$ .052 ; Koenker Chi-square $=3.5, \mathrm{p}=.06$ ). Thus, the null hypothesis that heteroskedasticity is not present (homoskedasticity) is therefore supported (Hayes \& Cai, 2007). Therefore, the results based on linear regression analysis are maintained. 


\section{Figure 1: Histogram for AC}

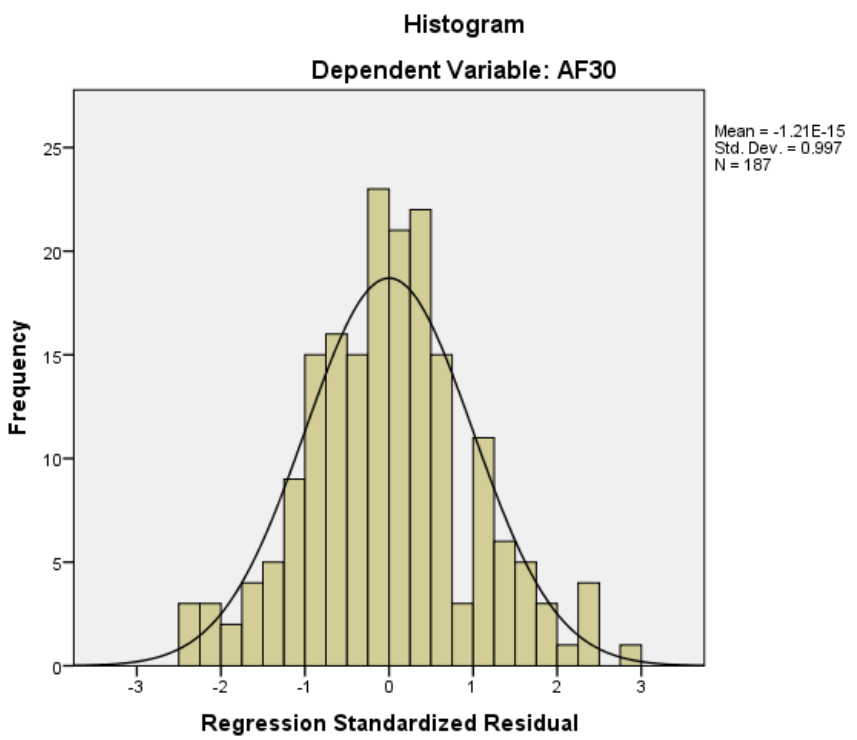

Source: Data analysis (2018)

Figure 2: Normal P-Plot for the Standardized Residual of AC

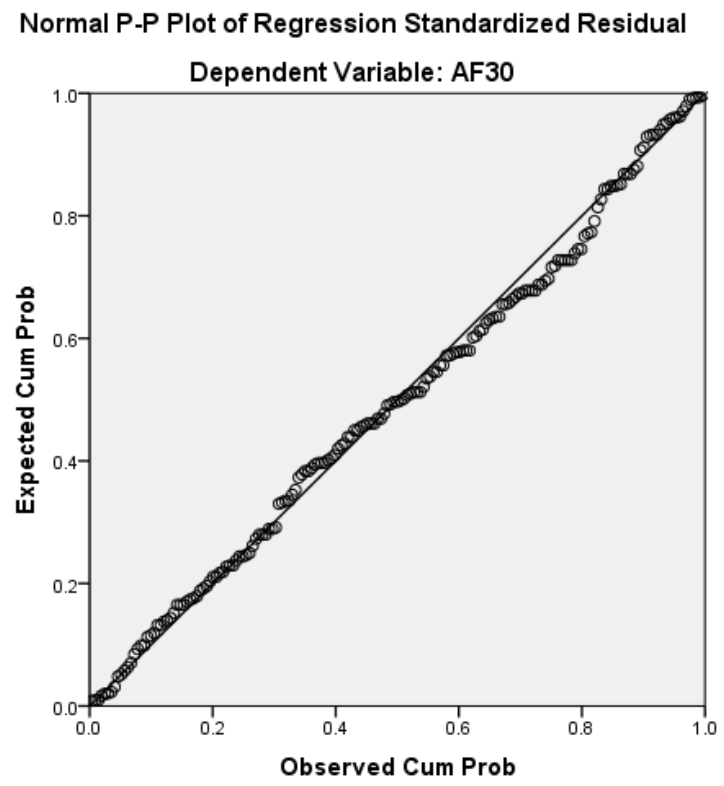

Source: Field data (2018) 


\section{Figure 3: Scatter plot for the Standardized residual for AC}

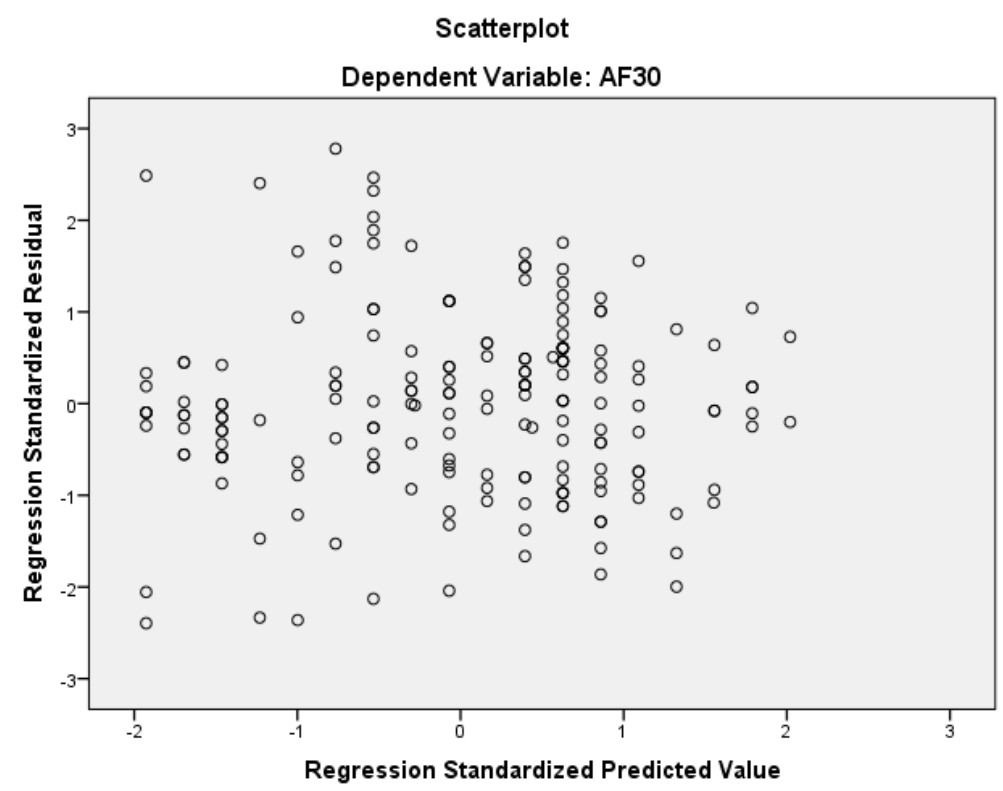

Source: Field data (2018)

\section{CONCLUSION}

Minimal studies on the relationship of psychological contract breach and organizational commitment have been done in Tanzania, particular at universities' academic staff. The universities influence on their expectations determine academic staff commitment. The decision to stay due to affection or fear of losing what has been gained over the years or just obligation to the university are depending on the degree of perceived psychological contract breach. If they perceive a high psychological contract, they decrease their commitment and eventually affect performance, and the last thing is to quit. However, if the degree of perceived psychological contract is minimal, then their affection and continuity and obligation will remain and therefore increase commitment to the universities.

It was found that psychological contract breach has a negative effect on affective commitment. The implication is that academic staffs stay at university because they have affection to be recognized as lecturers and professors. Therefore, their decisions to commit their working love to universities should be reciprocated by attractive academic human resource policies that are not only attracting and retain them but also motivate them to have high commitment. Policies like clear track line of talent management programmes, work-life balance, academic staff development and more extended stay before forced to retire are recommended. 
International Journal of Social Science and Economic Research

ISSN: 2455-8834

Volume: 05, Issue: 02 "February 2020"

\section{REFERENCES}

Allen, N. J. \& Meyer, J. P. (1990). The measurement and antecedents of affective, continuance and normative commitment to the organization. Journal of occupational psychology, 63(1), 1-18.

Albdour, A. A. \& Altarawneh, I. I. (2014). Employee engagement and organizational commitment: Evidence from Jordan. International journal of business, 19(2), 192.

Antonaki, X. E., \& Trivellas, P. (2014). Psychological contract breach and organizational commitment in the Greek banking sector: The mediation effect of job satisfaction. Procedia-Social and Behavioral Sciences, 148, 354-361.

Becker, H. S. (1960). Notes on the concept of commitment. American journal of Sociology, 66(1), 32-40.

Bergman, M. E. (2006). The relationship between affective and normative commitment: review and research agenda. Journal of Organizational Behavior, 645-663. DOI: 10.1002/job.372

Blau, P. (1964). Power and exchange in social life. NY: John Wiley \& Sons. Hainey, T.,

Benson, J., \& Brown, M. (2007). Knowledge workers: what keeps them committed; what turns them away. Work, employment and society, 21(1), 121-141.

Cassar, V. \& Briner, R. B. (2011). The relationship between psychological contract breach and organizational commitment: Exchange imbalance as a moderator of the mediating role of the violation. Journal of Vocational Behavior, 78(2), 283-289.Cohen, J. (n.d.). Statistical power analysis for the behavioural sciences. Birmingham: Lawrence Erlbaum Associates.

Chordiya, R., Sabharwal, M., \& Goodman, D. (2017). Affective organizational commitment and job satisfaction: A cross-national comparative study. Public Administration, 95(1), 178195.

Conway, N. \& Briner, R. B. (2002). A daily diary study of affective responses to psychological contract breach and exceeded promises. Journal of Organizational Behavior: The International Journal of Industrial, Occupational and Organizational Psychology and Behavior, 23(3), 287-302. 


\section{International Journal of Social Science and Economic Research}

ISSN: $2455-8834$

Volume: 05, Issue: 02 "February 2020"

Conway, N. \& Brinner, R. B. (2005). Understanding psychological contracts at work; A critical evaluation of theory and research. Oxford, UK: Oxford University Press

Conway, N. \& Coyle-Shapiro, J. A. M. (2006, August). Reciprocity and Psychological Contracts: Employee Performance and Contract Fulfillment. In Academy of Management Proceedings (Vol. 2006, No. 1, pp. Q1-Q6). Briarcliff Manor, NY 10510: Academy of Management.

Cropanzano, R., \& Mitchel, M. S. (2005). Social exchange theory: An interdisciplinary review. Journal of Management, 31 (6), 874-900

Chughtai, A. A., \& Zafar, S. (2006). Antecedents and consequences of organizational commitment among Pakistani university teachers.

De Aguiar Rodrigues, A. C., \& Bastos, A. V. B. (2010). Problemas conceituais e empíricos na pesquisa sobre comprometimento organizacional: uma análise crítica do modelo tridimensional de J. Meyer e N. Allen. Revista Psicologia: Organizações e Trabalho, 10(2), 129-144.

Fornes, S. L., \& Rocco, T. S. (2004). Commitment Elements Reframed (Antecedents \& Consequences) for Organizational Effectiveness. Online Submission.

Gasengayire, J. C., \& Ngatuni, P. (2019). Demographic Characteristics as Antecedents of Organisational Commitment. Pan-African Journal of Business Management, 3(1), 1-18.

George, D., \& Mallery, P. (2014). IBM SPSS; Statistics 21, Step by Step, A simple guide, and reference (13th).

Grama, B. G. (2017). Psychological Contract, Mediator Between Turnover Intention, Work Engagement and Type Of Labor Contract. Romanian Journal of Experimental Applied Psychology, 8.

Gunlu, E., Aksarayli, M., \& Perçin, N. Ş. (2010). Job satisfaction and organizational commitment of hotel managers in Turkey. International Journal of Contemporary Hospitality Management.

Hassan, S., \& Mahmood, B. (2016). Relationship between HRM practices and organizational commitment of employees: An empirical study of textile sector in Pakistan. International Journal of Academic Research in Accounting, Finance and Management Sciences, 6(1), 23-28. 


\section{International Journal of Social Science and Economic Research}

ISSN: $2455-8834$

Volume: 05, Issue: 02 "February 2020"

Ishengoma, J. M. (2017). The role of African flagship universities: The case of the University of Dar es Salaam. In Flagship universities in Africa (pp. 373-423). Palgrave Macmillan, Cham.

Hayes, A. F. \& Cai, L. (2007). Using heteroskedasticity- consistent standard error estimators in OLS regression: An introduction and software implementation. Behaviour Research Methods, 39(4), 709 -722. DOI: 10.3758/bf03192961

Hazrat, S. (2017). Psychological contract breach and affective commitment in the banking sector: The mediation effect of psychological violation and trust. Arabian Journal of Business and Management Review, 7(4), 1000320

Islam, T., Ahmad, U. N. B. U., Ali, G., Ahmed, I., \& Bowra, Z. A. (2013). Turnover intentions: The influence of perceived organizational support and organizational commitment. Procedia-Social and Behavioral Sciences, 103, 1238-1242.

Jonathan, H., Thibeli, M., \& Darroux, C. (2013). Impact investigation of organizational commitment on intention to leave of public secondary school teachers in Tanzania. Developing Country Studies, 3(11), 78-91.

Jonathan, H., Darroux, C., \& Thibeti, M. (2013). Exploring the effect of job satisfaction and demographic factors on affective, normative and continuance commitment: An empirical evidence of public secondary school teachers in Tanzania. Journal of Education and Practice, 4(23), 85-96.

Jung, H. S., \& Yoon, H. H. (2016). What does work meaning to hospitality employees? The effects of meaningful work on employees' organizational commitment: The mediating role of job engagement. International Journal of Hospitality Management, 53, 59-68.

Kärreman, D., \& Alvesson, M. (2004). Cages in tandem: Management control, social identity, and identification in a knowledge-intensive firm. Organization, 11(1), 149-175.

Khalili, A., \& Asmawi, A. (2012). Appraising the impact of gender differences on organizational commitment: Empirical evidence from a private SME in Iran. International Journal of Business and Management, 7(5), 100.

Khaleh, L. A. B. C., \& Naji, S. (2016). The relationship between organizational commitment components and organizational citizenship behavior in nursing staff. International Journal of Medical Research \& Health Sciences, 5(5), 173-179. 
International Journal of Social Science and Economic Research

ISSN: $2455-8834$

Volume: 05, Issue: 02 "February 2020"

Koskei, T. A., Kimutai, G., \& Bogonko, J. Continuance Commitment and Employee Performance at University of Eastern Africa, Baraton Kenya.

Levison, H., Price, C. R., Munden, K. J., Mandl, H. J. \& Solely, C. M. (1962). Management and mental health. Boston: Harvard University Press.

Marsh, H., Mclnerney, D. M., \& Craven, R. G. (2015). A PERSONAL AGENCY VIEUU (OF SELF-REGULATED.

Marri, M. Y. K., Sadozai, A. M., Zaman, H. M. F., \& Ramay, M. I. (2012). The impact of

Islamic work ethics on job satisfaction and organizational commitment: a study of agriculture sector of Pakistan. International Journal of Business and Behavioral Sciences, 2(12), 3245.

Mathieu, J. E., \& Zajac, D. M. (1990). A review and meta-analysis of the antecedents correlate, and consequences of organisational commitment. Psychological Bulletin, 108(2), 171191.

Meyer, J. P. (2001). A three-component conceptualization of organizational commitment. Journal of Human Resource Management Review, 1, (1), 62 - 89

Morrison, E. W. \& Robinson, S. L. (1997). When employees feel betrayed: A model of how psychological contract violation develops. Academy of Management Review, 22(1), $226-$ 256

Mowday, R. T., Porter, L. W., \& Steers, R. (1982). Organizational linkages: The psychology of commitment, absenteeism, and turnover.

Ngatuni, P. (2019). The relationship among employees' job attitudes of perceived supervisory support, job involvement and organisational commitment. Pan African Journal of Business Management, 3(2), forthcoming

Nguni, S., Sleegers, P., \& Denessen, E. (2006). Transformational and transactional leadership effects on teachers' job satisfaction, organizational commitment, and organizational citizenship behaviour in primary schools: The Tanzanian case. School Effectiveness and School Improvement, 17(2), 145-177

Pallant, J. (2010). SPSS survival manual: A step by step guide to data analysis using SPSS for Windows (Version 12). Sydney: Allen \& Unwin. 
Saunders, M., Lewis, P. \& Thornhil, A. (2012). Research methods for business students (6th Ed). London, Prentice Hall

Sial, M, A., Jilani, S. M. A., Imran, R., \& Zaheer, A. (2011). Effect of Human Resource

Shore, L. M., Tetrick, L. E., Taylor, M. S., Shapiro, J. A. M. C., Liden, R. C., Parks, J. M., ... \& Rousseau, D. M. (2004). The employee-organization relationship: a timely concept in a period of transition research in personnel and human resources management.

Tumwesigye, G. (2010). The relationship between perceived organisational support and turnover intentions in a developing country: The mediating role of organisational commitment. African Journal of Business Management, 4(6), 942.

Turnley, W. H., \& Feldman, D. C. (1999). A discrepancy model of psychological contract violations. Human resource management review, 9(3), 367-386.

Voon, M. L., Lo, M. C., Ngui, K. S., \& Ayob, N. B. (2011). The influence of leadership styles on employees' job satisfaction in public sector organizations in Malaysia. International Journal of Business, Management and Social Sciences, 2(1), 24-32. 